\title{
Article \\ Study on Indium (III) Oxide/Aluminum Thermite Energetic Composites
}

\author{
Pierre Gibot $^{1, * \mathbb{B}}$ and Estelle Puel ${ }^{2}$ \\ 1 NS3E laboratory, UMR 3208 ISL/CNRS/UNISTRA, French-German Research Institute of Saint-Louis (ISL), \\ 5 rue du Général Cassagnou, BP70034, 68301 Saint Louis, France \\ 2 Faculty of Science and Engineering, University of Toulouse III Paul Sabatier, 118 Route de Narbonne, \\ 31062 Toulouse, France; estelle.puel@isl.eu \\ * Correspondence: pierre.gibot@isl.eu
}

Citation: Gibot, P.; Puel, E. Study on Indium (III) Oxide/Aluminum Thermite Energetic Composites. J. Compos. Sci. 2021, 5, 166. https:// doi.org/10.3390/jcs5070166

Academic Editor:

Francesco Tornabene

Received: 31 May 2021

Accepted: 23 June 2021

Published: 26 June 2021

Publisher's Note: MDPI stays neutral with regard to jurisdictional claims in published maps and institutional affiliations.

Copyright: (C) 2021 by the authors. Licensee MDPI, Basel, Switzerland. This article is an open access article distributed under the terms and conditions of the Creative Commons Attribution (CC BY) license (https:// creativecommons.org/licenses/by/ $4.0 /$ )

\begin{abstract}
Thermites or composite energetic materials are mixtures made of fuel and oxidizer particles at micron-scale. Thermite reactions are characterized by high adiabatic flame temperatures $\left(>1000{ }^{\circ} \mathrm{C}\right)$ and high heats of reaction $\left(>\mathrm{kJ} / \mathrm{cm}^{3}\right)$, sometimes combined with gas generation. These properties strongly depend on the chemical nature of the couple of components implemented. The present work focuses on the use of indium (III) oxide nanoparticles as oxidizer in the elaboration of nanothermites. Mixed with an aluminum nanopowder, heat of reaction of the resulting $\mathrm{Al} / \mathrm{In}_{2} \mathrm{O}_{3}$ energetic nanocomposite was calculated and its reactive performance (sensitivity thresholds regarding different stimuli (impact, friction, and electrostatic discharge) and combustion velocity examined. The $\mathrm{Al} / \mathrm{In}_{2} \mathrm{O}_{3}$ nanothermite, whose heat of reaction was determined of about $11.75 \mathrm{~kJ} / \mathrm{cm}^{3}$, was defined as insensitive and moderately sensitive to impact and friction stimuli and extreme sensitive to spark with values $>100 \mathrm{~N}, 324 \mathrm{~N}$, and $0.31 \mathrm{~mJ}$, respectively. The spark sensitivity was decreased by increasing $\mathrm{In}_{2} \mathrm{O}_{3}$ oxidizer $(27.71 \mathrm{~mJ})$. The combustion speed in confined geometries experiments was established near $500 \mathrm{~m} / \mathrm{s}$. The nature of the oxidizer implemented herein within a thermite formulation is reported for the first time.
\end{abstract}

Keywords: nanothermites; $\operatorname{In}_{2} \mathrm{O}_{3}$; mechanical sensitivities; electrostatic discharge; combustion speed

\section{Introduction}

Thermites are described as highly exothermic reactions between a reducing metal and an oxide ceramic (both at the micron scale) to form a more stable oxide associated with the metal derived from the original ceramic. An illustration of this kind energetic mixture is the reaction (1) involving aluminum and iron (II, III) oxide for welding railway rails [1].

$$
8 \mathrm{Al}_{(\mathrm{s})}+3 \mathrm{Fe}_{3} \mathrm{O}_{4(\mathrm{~s})} \rightarrow 4 \mathrm{Al}_{2} \mathrm{O}_{3(\mathrm{~s})}+9 \mathrm{Fe}_{(\mathrm{s})}+\Delta \mathrm{H}
$$

with $\Delta \mathrm{H}$ the energy release during the reaction determined close to $-15.68 \mathrm{~kJ} / \mathrm{cm}^{3}(-3.68 \mathrm{~kJ} / \mathrm{g})$.

Over the past two decades these composite materials have attracted growing interest in pyrotechnics, with the elaboration of systems using nanoscale components to form what researchers call metastable intermolecular composites (MICs) or nanothermites. These energetic nano-systems have the advantage, on their micron scale counterparts, of reducing ignition delays (up to three order of magnitude) and increasing combustion speeds ( $<100 \mathrm{~m} / \mathrm{s}$ vs. $100-1000 \mathrm{~m} / \mathrm{s}$ ) and reproducibility [2]. As a reducing metal, aluminum (Al) is often chosen instead of magnesium $(\mathrm{Mg})$, zirconium $(\mathrm{Zr})$, and boron (B) because of a high heat of combustion of $31 \mathrm{~kJ} / \mathrm{g}$, its native alumina layer which makes handling safe, its low melting temperature $\left(T=660^{\circ} \mathrm{C}\right)$ leading to low ignition temperature, its high boiling temperature $\left(\mathrm{T}=2520^{\circ} \mathrm{C}\right)$ allowing high reaction temperatures, and its availability. In combination with $\mathrm{Al}$, a wide variety of oxide ceramics have been tabulated by Fischer and Grubelich [1] and many of them have been studied including molybdenum (VI) oxide 
$\left(\mathrm{MoO}_{3}\right)$, tungsten (VI) oxide $\left(\mathrm{WO}_{3}\right)$, iron (III) oxide $\left(\mathrm{Fe}_{2} \mathrm{O}_{3}\right)$, copper $(\mathrm{CuO})$ oxide, bismuth (III) oxide $\left(\mathrm{Bi}_{2} \mathrm{O}_{3}\right)$, and tin (IV) oxide $\left(\mathrm{SnO}_{2}\right)$ [3-27]. Surprisingly, to our knowledge, indium (III) oxide $\left(\mathrm{In}_{2} \mathrm{O}_{3}\right)$ has not yet been reviewed in the literature. However, $\operatorname{In}_{2} \mathrm{O}_{3}$ has an oxygen content of 60 atomic $\%$, an ability to release oxygen at $700{ }^{\circ} \mathrm{C}$ during the formation of indium (I) oxide $\left(\mathrm{In}_{2} \mathrm{O}\right)$, and a high density of $7.18 \mathrm{~g} / \mathrm{cm}^{3}$, making it an interesting potential candidate as an oxidizing agent in aluminum thermites [28,29]. Moreover, as $\mathrm{In}_{2} \mathrm{O}_{3}$ is an n-type semiconductor, explaining the literature on promising applications as gas sensors [30-35], it could prevent accidental ignition/combustion of $\mathrm{Al} / \mathrm{In}_{2} \mathrm{O}_{3}$ energetic composite materials during handling, by conduction of the electrical charges that can emanate from a human body. Indeed, the human body has the capacity to generate energy of a couple of tens of millijoules $[36,37]$ whereas, at the same time, thermite composites have an extremely low spark sensitivity with a defined threshold value of less than $1.5 \mathrm{~mJ}$ [38] Therefore, important precautions must be taken by operators to avoid dramatic accidents during handling, such as the use of grounded equipment (table, shoes, strap ... ). This sensitive aspect has become a research topic in the energetic materials community. The idea that emerges from this line of research is the addition of a third component within thermites to easily and quickly evacuate electrostatic charges. Carbon microstructures, metals, and intrinsically conducting polymers have been proposed [10,39-50].

In this paper, semiconductor indium (III) oxide material $\left(\operatorname{In}_{2} \mathrm{O}_{3}\right)$ was tested as an oxidizing component in highly reactive aluminothermal reactions. For that, a $\operatorname{In}_{2} \mathrm{O}_{3}$ powder was mixed with an aluminum nanopowder in stoichiometric conditions, and the performance of the resulting energetic mixture was studied in detail. The thermal, physicochemical, electrical, and sensitivity properties as well as the combustion behavior were investigated. $\mathrm{In}_{2} \mathrm{O}_{3}$ powders at the micro and nanometric scale were used for comparison purposes.

\section{Materials and Methods}

Aluminum nanopowder (Al, specific surface area (SSA) $=24 \mathrm{~m}^{2} / \mathrm{g}, 65.5 \mathrm{wt}$. \% of active aluminum content) was purchased from QNA Intrinsiq Materials Inc. (Rochester, NY, USA). Indium (III) oxide micron powder $\left(\mathrm{In}_{2} \mathrm{O}_{3 \_} \mu \mathrm{m}, \mathrm{SSA}=0.8 \mathrm{~m}^{2} / \mathrm{g}, 99.99 \%\right)$ and acetonitrile $\left(\mathrm{CH}_{3} \mathrm{CN}, 99 \%\right)$ were provided by Sigma Aldrich (Saint-Louis, MO, USA). Indium (III) oxide nanopowder $\left(\mathrm{In}_{2} \mathrm{O}_{3} \_\mathrm{nm}\right.$, apparent particle size (APS) $=20-70 \mathrm{~nm}, \mathrm{SSA}=9 \mathrm{~m}^{2} / \mathrm{g}, 99.995 \%$ ) was obtained from US Research Nanomaterials Inc. (Houston, TX, USA). Chemical reagents were used as received and without any further purification.

\subsection{Preparation of the $\mathrm{Al} / \mathrm{In}_{2} \mathrm{O}_{3}$ Energetic Composites}

By analogy with the work of Fischer and Grubelich [1], listing a plethora of fuel and oxidizer ingredients may consist of thermites composites, the likely exothermal stoichiometric reaction between aluminum and indium (III) oxide can be written as follows:

$$
2 \mathrm{Al}_{(\mathrm{s})}+\mathrm{In}_{2} \mathrm{O}_{3(\mathrm{~s})} \rightarrow \mathrm{Al}_{2} \mathrm{O}_{3(\mathrm{~s})}+2 \operatorname{In}_{(\mathrm{s})}
$$

with formation of alumina $\left(\mathrm{Al}_{2} \mathrm{O}_{3}\right)$ and indium metal $(\mathrm{In}$, melting and boiling temperatures of $156.5^{\circ} \mathrm{C}$ and $2072{ }^{\circ} \mathrm{C}$, respectively, and density of $7.31 \mathrm{~g} / \mathrm{cm}^{3}$ ) as combustion products. Generally, in pyrotechnics, the preparation of energetic thermites formulations calls on to the equivalence ratio $(\phi)$ concept whose formula is given in Equation (3):

$$
\phi=\frac{\left(\frac{F}{\mathrm{O}}\right) \exp .}{\left(\frac{\mathrm{F}}{\mathrm{O}}\right) \mathrm{st} .}
$$

with $\mathrm{F}$ and $\mathrm{O}$ the masses of pure fuel $(\mathrm{Al})$ and oxidizer $\left(\mathrm{In}_{2} \mathrm{O}_{3}\right)$ reactants, and the subscripts exp. and st. the experimental and stoichiometric conditions. For example, while a stoichiometric mixture will exhibit an equivalence ratio of 1 , fuel-rich and lean-fuel (or oxidizer-rich) mixtures will present $\phi$ ratio $>1$ and $<1$, respectively. 
Hence, firstly, compositions of $\mathrm{Al} / \mathrm{In}_{2} \mathrm{O}_{3}$ with equivalence ratio of 1 were prepared implementing either the $\operatorname{In}_{2} \mathrm{O}_{3}$ nano- or micron powder. This equivalence ratio was determined to lead to the highest reactive properties (ignition capacity and burning rate) of the $\mathrm{Al} / \mathrm{In}_{2} \mathrm{O}_{3}$ energetic composite material when investigating $\phi$ ranging from 0.8 to 1.6 (each 0.2). The different masses of $\mathrm{Al}$ and $\operatorname{In}_{2} \mathrm{O}_{3}$ powders ( $500 \mathrm{mg}$ of mixture in total) were suspended in an acetonitrile solution $(100 \mathrm{~mL})$, magnetically stirred $(1 \mathrm{~h})$ and sonicated $(3 \times 5 \mathrm{~min})$ in order to obtain a homogeneous and intimate mixing of the powders. The composites were dried at $80^{\circ} \mathrm{C}$ under reduced pressure (200 mbar) and then placed in an oven $\left(80^{\circ} \mathrm{C}, 4 \mathrm{~h}\right)$. The resulting powdered thermites were identified as $\mathrm{Al} / \mathrm{In}_{2} \mathrm{O}_{3}-\mathrm{nm}$ and $\mathrm{Al} / \mathrm{In}_{2} \mathrm{O}_{3}-\mu \mathrm{m}$ owing to the use of the nano or micrometric indium (III) oxide material, respectively.

\subsection{Characterization Techniques}

The non-energetic properties of the $\mathrm{Al} / \mathrm{In}_{2} \mathrm{O}_{3}$ thermites were determined by using the usual laboratory characterization techniques as the X-ray diffraction (XRD), the scanning electron microscopy (SEM), and the nitrogen physisorption measurements.

$\mathrm{X}$-ray powder diffraction patterns of the energetic composites were recorded on a D8Advance diffractometer (Bruker, Billerica, MA, USA) equipped with a $\mathrm{Cu}-\mathrm{K}$ radiation and a Lynxeye detector and operating at $40 \mathrm{kV}-40 \mathrm{~mA}$. The diffractograms were collected between $10-80^{\circ}$ with a step size of $0.01^{\circ}$. The microstructures of the composites were observed by using a Nova Nano-SEM 450 microscope (FEI, Tokyo, Japan) working with a $10 \mathrm{kV}$ current. Prior to the analysis, the samples were sputtered with a 7-8 nm layer of gold. The electron diffusion scattering (EDS) was used to establish chemical elements maps (Al and In) of both energetic mixtures. Nitrogen physisorption measurements, carried out on an ASAP 2020 apparatus (Micromeritics, Norcross, CA, USA), were performed to determine the specific surface area (SSA) of the different powders consisting of the energetic composites. The powders were previously outgassed at $200{ }^{\circ} \mathrm{C}$ for $6 \mathrm{~h}$ under vacuum. The SSAs were determined according to the Brunauer-Emmett-Teller (BET) theory in the $0.05-0.20$ relative pressure zone. The electrical conductivity measurements were achieved according to the two-point probing method described in [49]. Briefly, samples (50 mg) were poured in an insulating plastic mold and two copper electrodes, connected to a 2010 multimeter (Keithley, Beaverton, OR, USA), were placed to each end. A 2.5 MPa pressure was applied during $60 \mathrm{~s}$. before recording the resistance values. The electrical conductivity ( $\sigma \mathrm{n}$ Siemens per meter, $\mathrm{S} / \mathrm{cm}$ ) was determined by applying the equation below:

$$
\sigma=\frac{1}{\mathrm{R}} \times \frac{\mathrm{e}}{\mathrm{S}}
$$

where R, e, and S correspond to the resistance (in Ohms, $\Omega$ ), thickness (in centimeter), and section surface (in square centimeter), respectively, of the material thought by the current.

In regard to safety principles, for example, to assure the safe handling of the matter by an operator, the $\mathrm{Al} / \operatorname{In}_{2} \mathrm{O}_{3}$ energetic composites were subjected to diverse stresses as mechanical (impact and friction) and electrostatic discharge (ESD) tests. The sensitivities investigation was performed on a fall-hammer, a Julius Peter BAM, and an ESD 2008A device, respectively. The different principles governed by these tests are described in $[10,27,42,44,49,50]$. Briefly, the impact test consists of crushing matter between two metal cylinders in which the top one is bumped by a weight fall of a defined height. Regarding the friction test, the matter is scrapped between a stick and a plate, both in ceramic, and the intensity of the applied force is determined both by a weight and its position on the lever carrying the stick. Regarding the ESD test, the matter is submitted to the crossing of a stark created between two electrodes (distant of $1 \mathrm{~mm}$ ) and whose intensity is defined by the high voltage and capacity of a condensator used. The sensitivity threshold values of the material considered toward each test, expressed in joules (J), newton (N), and millijoules (mJ), respectively, correspond to six negative consecutive tests (no reaction). 
Finally, the reactive properties of the $\mathrm{Al} / \mathrm{In}_{2} \mathrm{O}_{3}$ energetic composites were determined through a thermal analysis and the determination of the combustion velocity.

The ignition ability of the different $\mathrm{Al} / \mathrm{In}_{2} \mathrm{O}_{3}$ formulations were determined by using an optical flash device delivering an energy density of $0.11 \mathrm{~J} / \mathrm{cm}^{2}$ [51]. For that, $10 \mathrm{mg}$ of energetic composite material was put on a glass substrate $(1 \mathrm{~mm}$ thickness) and placed on top of the device. A Photron high-speed camera working at 10,000 frames per second was used to take videos of the combustion events. For the most reactive systems, the combustion velocities were determined according to the schematic reported in [10]. The thermites were loaded in polymethylmetacrylate tubes (PMMA, inner diameter $=4 \mathrm{~mm}$, length $=150 \mathrm{~mm}$ ) until the powder was flush with the opening, taking care to have a constant loading density all over the tubes. In respect to the second criteria, multiple $50 \mathrm{mg}$-powder loadings were operated in controlling the filling height. The tube was placed horizontally in a combustion tank and a laboratory-made chemical igniter (as a replacement for the optical flash device) was placed at approximately $1 \mathrm{~mm}$ in front of one end. To record the combustion events, the Photron high-speed camera was set at 50,000 frames per second. From the video recordings, the combustion speeds were determined by the position of the reaction front (forward-most luminous pixel) with respect to time. The combustion velocities of the energetic formulations were averaged on four combustion experiments.

\section{Results and Discussion}

\subsection{Characterization of the $\mathrm{Al} / \mathrm{In}_{2} \mathrm{O}_{3}$ Energetic Composite Materials}

As the $\mathrm{Al} / \mathrm{In}_{2} \mathrm{O}_{3}$ energetic formulation has never been investigated before, some intrinsic properties were determined, and the calculations were given. Some physicochemical data of the components involved in this equation are gathered in Table 1.

Table 1. Physico-chemical data of the components involved in the $\mathrm{Al} / \mathrm{In}_{2} \mathrm{O}_{3}$ thermite.

\begin{tabular}{cccc}
\hline Material & Molar Mass $(\mathbf{g} / \mathbf{m o l})$ & Density $\left(\mathbf{g} / \mathbf{c m}^{\mathbf{3}}\right)$ & $\left.\boldsymbol{\Delta H}_{\mathbf{f}}^{\circ} \mathbf{( 2 9 8} \mathbf{K}, \mathbf{~ k J} / \mathbf{m o l}\right)$ \\
\hline $\mathrm{Al}$ & 26.98 & 2.70 & 0 \\
$\mathrm{In}_{2} \mathrm{O}_{3}$ & 7.18 & 7.18 & -925.8 \\
$\mathrm{Al}_{2} \mathrm{O}_{3}$ & 3.05 & 3.05 & 1675.7 \\
$\mathrm{In}$ & 7.31 & 7.31 & 0 \\
\hline
\end{tabular}

The theoretical maximum density (TMD) of the $\mathrm{Al} / \mathrm{In}_{2} \mathrm{O}_{3}$ energetic mixture can be calculated from the Formula (5) described below:

$$
T M D=1 / \sum_{i=1}^{n} \frac{X i}{\rho i}
$$

where $X$ and $\rho$ characterize the mass fraction and density, respectively, of the chemical $i$. Assuming as ingredients within the considered reactive material are pure aluminum (16.3 wt. \%), and indium (III) oxide $\left(\mathrm{In}_{2} \mathrm{O}_{3}, 83.7 \mathrm{wt} . \%\right)$ powders, the TMD was calculated equal to $5.65 \mathrm{~g} / \mathrm{cm}^{3}$ for stoichiometric conditions (equivalence ratio $(\phi)$ of 1 ).

The heat of reaction of the Equation (2), considered total at $298 \mathrm{~K}$, was calculated according to the Hess law given in (6):

$$
\Delta H^{\circ} \text { reaction }=\sum \Delta H^{\circ} f_{(\text {Products, } 298 K)}-\sum \Delta H^{\circ} f_{(\text {Reactants, } 298 K)}
$$

where $\Delta H^{\circ} f$ are the standard enthalpy of formation of the different compounds participating to the reaction. From the different thermochemical data gathered in Table 1, combined with the chemical Equation (1), a heat of reaction at $298 \mathrm{~K}\left(\Delta H^{\circ}\right.$ reaction) of $-749.9 \mathrm{~kJ}$ was then calculated for the $\mathrm{Al} / \operatorname{In}_{2} \mathrm{O}_{3}$ energetic composite materials. Taking into account the mass and density of the $\mathrm{Al} / \mathrm{In}_{2} \mathrm{O}_{3}$ mixture, the heat of reaction was established at $-2.26 \mathrm{~kJ} / \mathrm{g}$ and $-12.77 \mathrm{~kJ} / \mathrm{cm}^{3}$, respectively. 
Figure 1 shows the microstructure of the two $\mathrm{Al} / \mathrm{In}_{2} \mathrm{O}_{3}$ composite materials. Based on microscopic electron analyses of the individual powders $\left(\mathrm{Al}, \mathrm{In}_{2} \mathrm{O}_{3 \_} \mathrm{nm}\right.$ and $\operatorname{In}_{2} \mathrm{O}_{3-} \mu \mathrm{m}-$ Supporting Information S1), the $\mathrm{Al} / \mathrm{In}_{2} \mathrm{O}_{3} \_\mu \mathrm{m}$ thermite (Figure $1 \mathrm{~A}$ ) can be described as a coating of aluminum particles on indium (III) oxide agglomerates, since spherical particles are clearly observed on the surface of highly faceted micro sized agglomerates. In contrast, for the $\mathrm{Al} / \mathrm{In}_{2} \mathrm{O}_{3}$ nm thermite (Figure 1B), the two components appear to be homogeneously mixed because at every point in the image, spherical, and undefined-shape particles (both at nanoscale), identified as $\mathrm{Al}$ and $\mathrm{In}_{2} \mathrm{O}_{3}$, respectively, are observed. Consequently, in this formulation the contact surface area between the two ingredients is better than for the $\mathrm{Al} / \mathrm{In}_{2} \mathrm{O}_{3} \_\mu \mathrm{m}$ material (Figure $1 \mathrm{~A}$ ). The textural properties of these composite materials, more particularly the specific surface area (as(composite)), were determined from krypton physisorption measurements at $77 \mathrm{~K}$. Specific surface areas values of $3.5 \mathrm{~m}^{2} / \mathrm{g}$ and $5.6 \mathrm{~m}^{2} / \mathrm{g}$ were then determined for the $\mathrm{Al} / \mathrm{In}_{2} \mathrm{O}_{3} \_\mu \mathrm{m}$ and $\mathrm{Al} / \mathrm{In}_{2} \mathrm{O}_{3}$ nm composite materials, respectively.
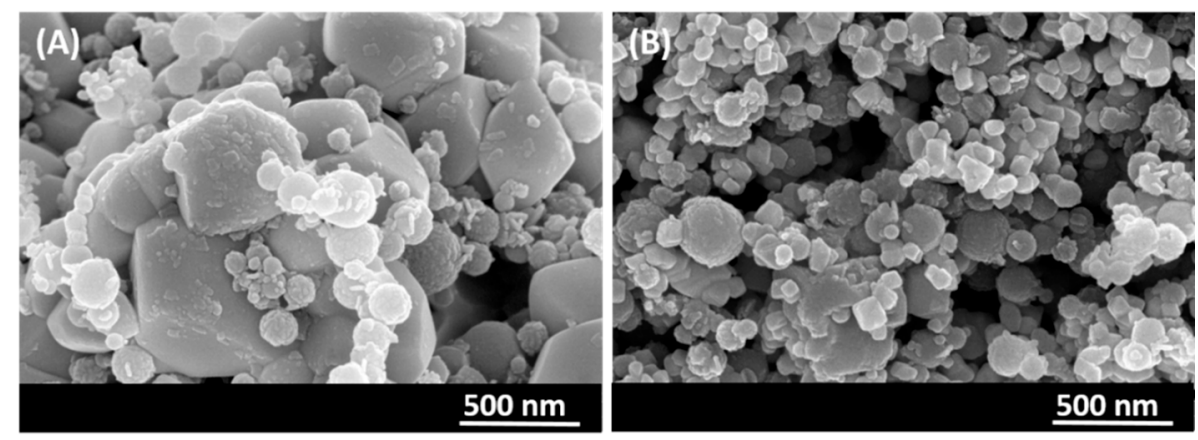

Figure 1. SEM images of the (A) $\mathrm{Al} / \mathrm{In}_{2} \mathrm{O}_{3-} \mu \mathrm{m}$ and (B) $\mathrm{Al} / \mathrm{In}_{2} \mathrm{O}_{3}$ nm energetic formulations, respectively.

Further characterizations of the $\mathrm{Al} / \mathrm{In}_{2} \mathrm{O}_{3}$ energetic composites were performed in term of electrical conductivity because of the semiconducting character of the indium (III) oxide material [35]. For comparison purposes, the electrical properties of the diverse powders constituting the mixtures were also determined. The principle was based on a two-point method as described previously. Table 2 compiles the conductivity data of the samples with the corresponding density. As the density is similar for samples and energetic mixtures of similar chemical composition, the conductivity values can be compared.

Table 2. Electrical conductivity of the aluminum, indium (III) oxide powders and aluminum/indium (III) oxide energetic composite materials (at an equivalence ratio $\phi$ of 1 ). The density of the pelletized samples is expresses in term of TMD \% where TMD represents the theoretical maximum density of the sample.

\begin{tabular}{ccc}
\hline Material & $\sigma(\mathbf{S} / \mathbf{c m})$ & Density (TMD \%) \\
\hline $\mathrm{Al}$ & $4.44 \times 10^{-8}$ & 43.5 \\
$\mathrm{In}_{2} \mathrm{O}_{3 \_} \mu \mathrm{m}$ & $2.55 \times 10^{-2}$ & 41.5 \\
$\mathrm{In}_{2} \mathrm{O}_{3 \_} \mathrm{nm}$ & $7.15 \times 10^{-3}$ & 35.4 \\
$\mathrm{Al} / \mathrm{In}_{2} \mathrm{O}_{3 \_} \mu \mathrm{m}$ & $1.19 \times 10^{-1}$ & 46.1 \\
$\mathrm{Al} / \mathrm{In}_{2} \mathrm{O}_{3 \_} \mathrm{nm}$ & $7.11 \times 10^{-3}$ & 41.8 \\
\hline
\end{tabular}

As expected, both indium (III) oxide powders exhibit typical semiconductor properties with conductivities between $10^{-3}$ and $10^{-2} \mathrm{~S} / \mathrm{cm}$. In contrast, the aluminum metal nanopowder is characterized by an extremely low conductivity $\left(10^{-8} \mathrm{~S} / \mathrm{cm}\right)$, which is characteristic of insulating materials [51]. This result can be explained by the microstructure of the $\mathrm{Al}$ particle, which is described by a core-shell structure, i.e., a metallic $\mathrm{Al}$ core covered with an amorphous alumina native layer $\left(\mathrm{Al}_{2} \mathrm{O}_{3}\right) \cdot \mathrm{Al}_{2} \mathrm{O}_{3}$ is known as to be an insulating 
material with a resistivity value $>10^{12} \Omega . \mathrm{m}$ [52]. Now, concerning the two thermite materials, two main important facts can be emphasized. The first one is the conductive character of both energetic systems with conductivity values in the same level of magnitude than indium (III) oxide powders that may be explained by the volume predominance of $\operatorname{In}_{2} \mathrm{O}_{3}$ over $\mathrm{Al}$ ( 57 vs. 43 vol. \%, respectively, according to an equivalence ratio of 1 ). Then, the second point is the high value of conductivity of the $\mathrm{Al} / \mathrm{In}_{2} \mathrm{O}_{3} \_\mu \mathrm{m}$ composite compared to the micron sized $\operatorname{In}_{2} \mathrm{O}_{3}$ powder consisting of it. This result may be supported by a possible crushing of the $\mathrm{Al}$ particles during the pressurization step for the conductivity measurements $(\mathrm{P}=2.5 \mathrm{MPa})$, leading to crackling alumina layer and consequently exposing the highly electrical conductive aluminum core $\left(\sigma_{\text {th. }}=10^{6} \mathrm{~S} / \mathrm{m}\right)$.

\subsection{Sensitivity Properties of the $\mathrm{Al} / \mathrm{In}_{2} \mathrm{O}_{3}$ Energetic Composite Materials}

The sensitivity thresholds of the $\mathrm{Al} / \mathrm{In}_{2} \mathrm{O}_{3}$ thermites, as a function of the oxidizer particle size, are gathered in Table 3. It should be noted the upper mathematical sign means that the value noted is the highest value that can be determined from our mechanical test's apparatus.

Table 3. Sensitivity thresholds of the aluminum/indium (III) oxide energetic composite materials (at an equivalence ratio $\phi$ of 1 ) as a function of the oxidizer particle size.

\begin{tabular}{cccc}
\hline Sensitivity Test & Impact (J) & Friction (N) & ESD (mJ) \\
\hline $\mathrm{Al} / \mathrm{In}_{2} \mathrm{O}_{3 \_} \mu \mathrm{m}$ & $>100$ & $>360$ & 27.71 \\
$\mathrm{Al} / \mathrm{In}_{2} \mathrm{O}_{3 \_} \mathrm{nm}$ & $>100$ & 324 & 0.31 \\
\hline
\end{tabular}

As can be seen, the two energetic mixtures show similar data, especially for mechanical stimuli with high threshold values, i.e., greater than $100 \mathrm{~J}$ and at least $324 \mathrm{~N}$ for the impact and friction tests, respectively. In comparison with the sensitivity classes established by NATO for energetic materials $[53,54]$, the $\mathrm{Al} / \mathrm{In}_{2} \mathrm{O}_{3}-\mu \mathrm{m}$ formulation can be classified as mechanically insensitive with values significantly higher than the standards $40 \mathrm{~J}$ and $360 \mathrm{~N}$. Concerning the $\mathrm{Al} / \mathrm{In}_{2} \mathrm{O}_{3} \_\mathrm{nm}$ mixture, while it is insensitive to impact test, it is ranked as moderately sensitive to friction test since the threshold value obtained is in the range 80-360 N. Now, with regard to electrostatic discharge (ESD), taking into consideration the discharge capacity of a human body estimated at a few tens of millijoules [36,37], the $\mathrm{Al} / \mathrm{In}_{2} \mathrm{O}_{3}-\mu \mathrm{m}$ composite is safer to handle than its nanometric size counterpart with a value of $27.17 \mathrm{~mJ}$ as opposed to $0.31 \mathrm{~mJ}$. The latter value characterizes a composite that is extremely sensitive to spark. This result can be directly supported by the electrical conductivity values previously determined for energetic formulations. Indeed, micronsized $\mathrm{Al} / \mathrm{In}_{2} \mathrm{O}_{3}$ composite materials have a higher current conduction ability than their nano-sized counterpart. This capacity makes it easier to dissipate electric charges in the powder, thus avoiding an accumulation or a higher energy density at the $\mathrm{Al} / \mathrm{In}_{2} \mathrm{O}_{3}$ interphase level which could lead to an accidental ignition.

\subsection{Ignition Ability of the $\mathrm{Al} / \mathrm{In}_{2} \mathrm{O}_{3}$ Energetic Composite Materials}

The ignition ability of both composite materials was evaluated by means of an optical flash igniter (density energy of $0.11 \mathrm{~J} / \mathrm{cm}^{2}$ ) and representative sequences of ignition/combustion images, in unconfined mode, are shown in Figure 2.

Obviously, the reactive behaviors of the two $\mathrm{Al} / \mathrm{In}_{2} \mathrm{O}_{3}$ energetic materials were very different. Indeed, while the $\mathrm{Al} / \mathrm{In}_{2} \mathrm{O}_{3} \_\mu \mathrm{m}$ formulation burns slowly and in an incomplete way, since reactive components were found as residues on the glass substrate after the ignition experiment, the $\mathrm{Al} / \mathrm{In}_{2} \mathrm{O}_{3} \_\mathrm{nm}$ energetic material burns violently and only traces of combustion products were found on the glass substrate. In addition, the appearance of the flame is totally different with successive projections of incandescent particles (crackling) for the $\mathrm{Al} / \mathrm{In}_{2} \mathrm{O}_{3} \_\mu \mathrm{m}$ system, and the formation of a fireball moving over the top of the device and accompanied by a loud noise for the $\mathrm{Al} / \mathrm{In}_{2} \mathrm{O}_{3} \_$nm system. Conse- 
quently, the $\mathrm{Al} / \mathrm{In}_{2} \mathrm{O}_{3} \_\mathrm{nm}$ material exhibits a higher ignition/combustion ability than the $\mathrm{Al} / \mathrm{In}_{2} \mathrm{O}_{3} \_\mu \mathrm{m}$ composite. To explain such a result, the differences in textural properties and homogeneity of the two energetic materials can be suggested. Considering equivalent densities for the two formulations (5-10\% of the TMD [3]), the specific surface area developed by the mixtures $\left(\mathrm{a}_{\mathrm{s} \text { (composite) }}\right)$ defines the available surface area of the mixture where the combustion reaction can take place [55]. Therefore, the higher the $\mathrm{a}_{\mathrm{s} \text { (composite) }}$ is, the easier the ignition is. As a reminder, the $\mathrm{a}_{\mathrm{s} \text { (composite) }}$ of $\mathrm{Al} / \mathrm{In}_{2} \mathrm{O}_{3}$ nm has been determined higher than the $\mathrm{a}_{\mathrm{s} \text { (composite) }}$ of $\mathrm{Al} / \mathrm{In}_{2} \mathrm{O}_{3} \_\mu \mathrm{m}\left(5.6\right.$ vs. $\left.3.5 \mathrm{~m}^{2} / \mathrm{g}\right)$. Moreover, as it is generally accepted, the low scale homogeneity of a given medium is greater when chemical species of same dimension (and morphology) are used compared to particles of different sizes. However, the homogeneity of a medium is one of the parameters that makes the propagation of the combustion flame easier and faster.

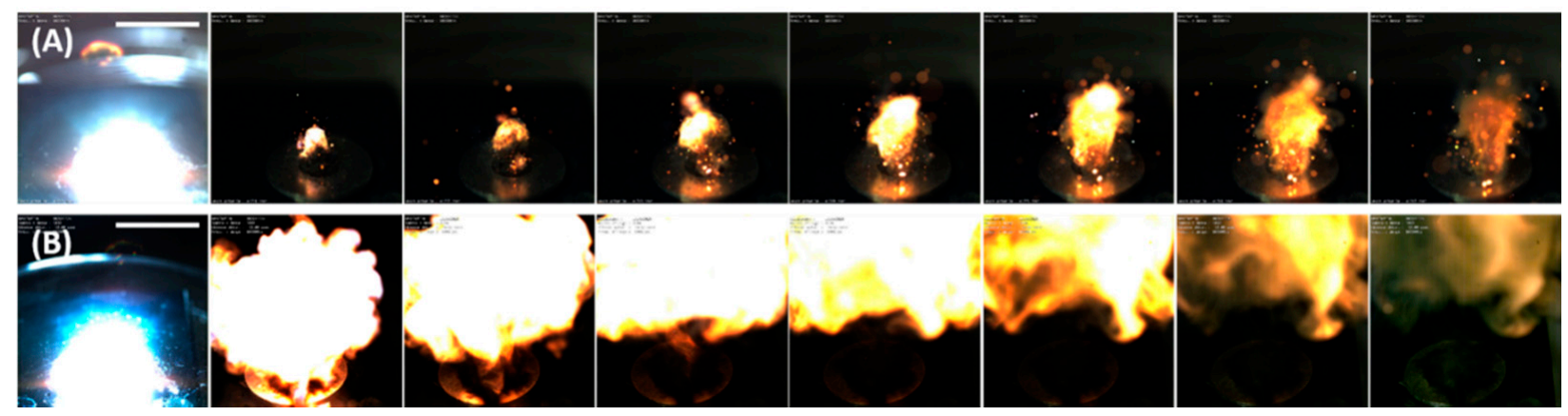

Figure 2. Sequences of combustion images of the (A) $\mathrm{Al} / \mathrm{In}_{2} \mathrm{O}_{3}-\mu \mathrm{m}$ (time interval between images of $10 \mathrm{~ms}$ ) and (B) $\mathrm{Al} / \mathrm{In}_{2} \mathrm{O}_{3}$ nm energetic formulations, respectively with an interval of time between images of $10 \mathrm{~ms}$ and $1 \mathrm{~ms}$, respectively. The white scale bar (on top on first images) represents $20 \mathrm{~mm}$.

In a second step, the combustion products of the $\mathrm{Al} / \mathrm{In}_{2} \mathrm{O}_{3}$ reacting pair were characterized to validate the Equation (2). Figure 3 displays a photograph and an XRD pattern of the combustion residues coated on the glass substrate after the burn experiment of the $\mathrm{Al} / \mathrm{In}_{2} \mathrm{O}_{3}$ nnm energetic system. The macroscopic view in insert of Figure 3 shows a combustion zone embedded in the glass substrate with a grey-brownish star shape. The branches of the star clearly indicate that the exothermic reaction is violent and spreads in all directions in space.

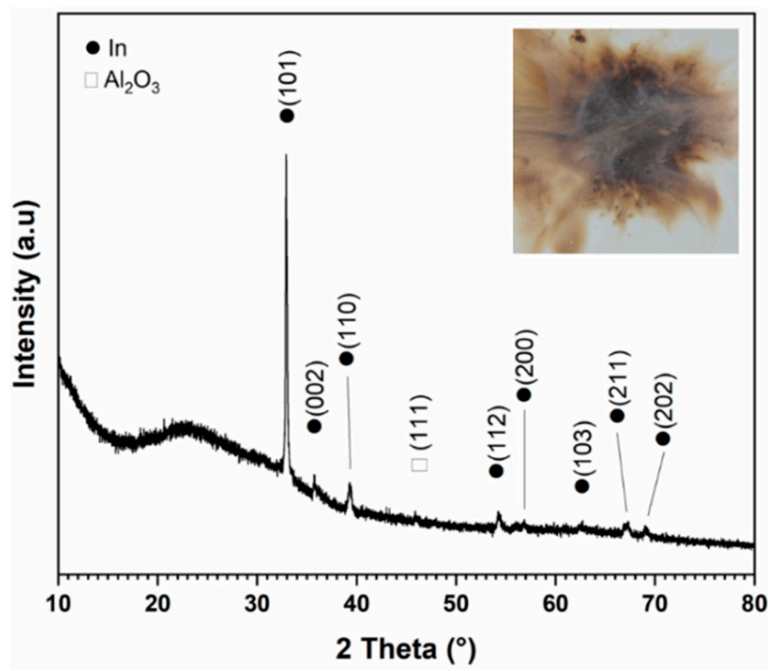

Figure 3. XRD pattern and photograph (insert) of the combustion products of the $\mathrm{Al} / \mathrm{In}_{2} \mathrm{O}_{3} \_\mathrm{nm}$ energetic composite material. 
With regard to the X-ray diffraction pattern (Figure 3), which was obtained directly from the substrate, the diffraction peaks have been indexed, for the most intense ones, by the metal indium (In) described by a body-centered tetragonal crystal lattice with the $\mathrm{I} 4 / \mathrm{mmm}$ space group (JCPDS card No. 85-1409) and then by the alumina phase $\left(\gamma-\mathrm{Al}_{2} \mathrm{O}_{3}\right)$ defined by a cubic structure and the Fd-3m space group (JCPDS card No. 029-0063). The broad peak located at 2theta ranging from $15^{\circ}$ to $40^{\circ}$ was attributed to the glass substrate. The identification of the products is consistent with the combustion reaction suggested in the experimental section for the $\mathrm{Al} / \mathrm{In}_{2} \mathrm{O}_{3}$ energetic thermite system.

\subsection{Combustion Velocity of the $\mathrm{Al} / \mathrm{In}_{2} \mathrm{O}_{3} \_n m$ Energetic Composite Material}

Based on the previous result on ignition, the combustion rate of the $\mathrm{Al} / \mathrm{In}_{2} \mathrm{O}_{3}$ energetic system, in a confined environment, was only determined for the nanoscale formulation since the micron system does not lead to complete combustion. For this purpose, a burning tube experiment was carried out as described in Section 2.2. A series of four tests was performed to average the combustion speed. The average loading density of the tubes filling with the stoichiometric $\mathrm{Al} / \mathrm{In}_{2} \mathrm{O}_{3} \_\mathrm{nm}$ composition was calculated to be $0.73 \pm 0.01 \mathrm{~g} / \mathrm{cm}^{3}$ (Supporting Information S2). The low standard deviation indicates a reliable and reproducible filling method. From Equation (5), and taking into account the fact that the $\mathrm{Al}$ nanopowders is really made of pure aluminum $\left(\mathrm{Al}, 67.75 \mathrm{wt} . \%, 2.70 \mathrm{~g} / \mathrm{cm}^{3}\right)$ and amorphous alumina $\left(\mathrm{Al}_{2} \mathrm{O}_{3}, 32.25 \mathrm{wt} . \%, 3.05 \mathrm{~g} / \mathrm{cm}^{3}\right)$, the TMD was recalculated equal to $5.29 \mathrm{~g} / \mathrm{cm}^{3}$. Thus, the current experimental loading density corresponds to $13.8 \%$ of this TMD, thus characterizing a loose powder [3]. Figure 4 displays a sequence of images of burning experiments of the $\mathrm{Al} / \mathrm{In}_{2} \mathrm{O}_{3} \_\mathrm{nm}$ composite material. The reaction front, materialized by the brightest pixels, can be followed by the displacement of this luminescent signal along the entire length of the tube. As can be seen, the movement of the combustion front can be divided into two stages: an initial short transient of about 0.12-0.16 ms (Figure 4-images 1 to 4) characterizing an ignition phase, followed by a second stage where the flame front moves continuously as a function of time, reflecting a self-propagating combustion reaction. From the distance travelled as a function of time (Supporting Information S3) and by applying a linear regression over a defined period of time where the distance/time ratio appears to be constant (distance travelled through the tube of approximately $100 \mathrm{~mm}$ ), an average combustion rate of $481 \pm 12 \mathrm{~m} / \mathrm{s}$ was thus determined for the $\mathrm{Al} / \mathrm{In}_{2} \mathrm{O}_{3} \_\mathrm{nm}$ energetic material, formulated from an equivalence ratio (ф) of 1.

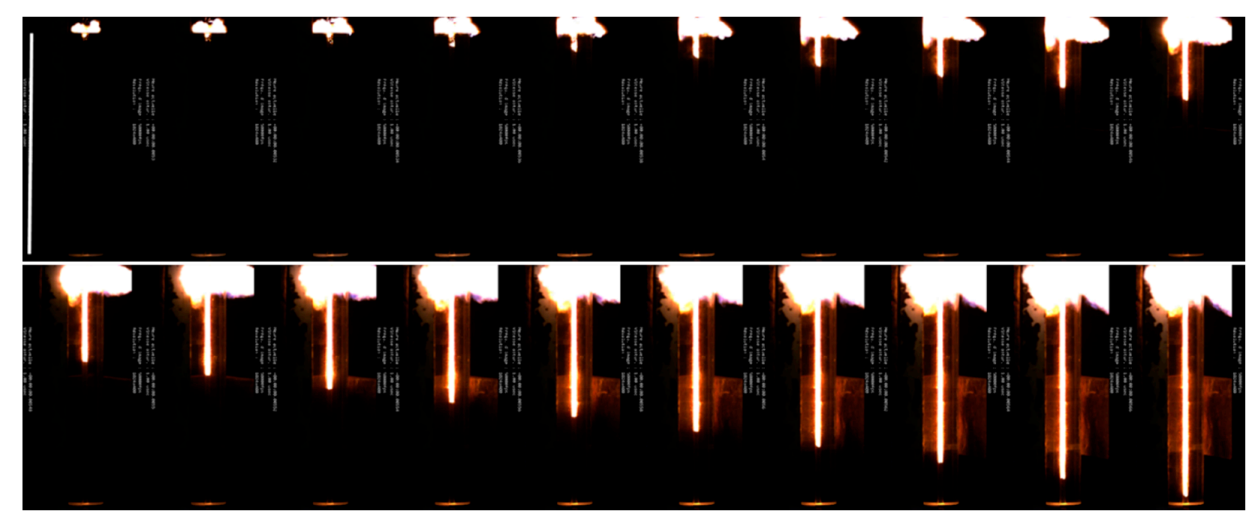

Figure 4. Images captured from the combustion of the $\mathrm{Al} / \mathrm{In}_{2} \mathrm{O}_{3} \_\mathrm{nm}$ energetic composite material. The equivalence ratio $(\phi)$ was fixed at 1 . The elapsed time between images was $40 \mu \mathrm{s}$. The white scale bar (at left on first image) represents the tube length $(150 \mathrm{~mm})$.

In an attempt at positioning the $\mathrm{Al} / \mathrm{In}_{2} \mathrm{O}_{3}$ energetic composite material within the class of energetic formulations, its characteristics and performance were compared with some nanothermites $\left(\mathrm{Al} / \mathrm{Fe}_{2} \mathrm{O}_{3}, \mathrm{Al} / \mathrm{WO}_{3}, \mathrm{Al} / \mathrm{CuO}, \mathrm{Al} / \mathrm{Bi}_{2} \mathrm{O}_{3}, \mathrm{Al} / \mathrm{SnO}_{2}\right.$, and $\left.\mathrm{Al} / \mathrm{MoO}_{3}\right)$ [27]. It is important to keep in mind that performance of nanothermites can depend on various 
parameters (equivalence ratio, granulometry of the components, experimental procedure); this comparison is for information purposes only. With a heat of reaction of $-12.77 \mathrm{~kJ} / \mathrm{cm}^{3}$, the $\mathrm{Al} / \mathrm{In}_{2} \mathrm{O}_{3}$ reactive mixture is less exothermic than the above-mentioned compositions whose heats releases are approximately around -15 to $-21 \mathrm{~kJ} / \mathrm{cm}^{3}$. Regarding the sensitivity properties, the composite nanomaterial investigated in this work is identical in some points with these composites, in particular due to an insensitivity to impact stimulus, and a very low sensitivity threshold to electrostatic discharges. It can be noted that it is less sensitive to friction test than $\mathrm{Al} / \mathrm{CuO}$ and $\mathrm{Al} / \mathrm{Bi}_{2} \mathrm{O}_{3}$ materials. With respect to the ESD sensitivity, the storage of $\mathrm{Al} / \mathrm{In}_{2} \mathrm{O}_{3}$ energetic formulation must be done via conductive cells and the material must be handled by grounded operators. Finally, concerning the reactive properties, the $\mathrm{Al} / \mathrm{In}_{2} \mathrm{O}_{3}$ material exhibits a burning speed of about $500 \mathrm{~m} / \mathrm{s}$ which is slightly below to the other MICs mentioned above (i.e., combustion velocities between $500-1000 \mathrm{~m} / \mathrm{s}$ ) [27]. With a regard to the combustion products, metallic indium presents intrinsic properties that could prove complementary or even more interesting properties compared to those of tin, iron, molybdenum, and tungsten metals, depending on the targeted applications. Some physical data of these metals have been collected in Table 4 [56]. For example, indium metal has a very low melting point of $156.6^{\circ} \mathrm{C}$, compared to its counterparts ( $\mathrm{T}_{\mathrm{m}}$ ranging from 231.9 to $3422^{\circ} \mathrm{C}$ ), associated with a high boiling point which gives it a very wide liquid range $\left(1800{ }^{\circ} \mathrm{C}\right)$ and especially starting at very low temperatures. Fluid indium can therefore be used for filling interstices or pores in materials which cannot be exposed to very high temperatures over very long periods of time. Applications may be the realization of short-circuits or, on the contrary, ensuring current or heat through due to conductivity properties which characterize indium, that are similar to other metals expected for such applications (Table 4). Finally, indium is known as a material of interest in the sealing of metal-to-metal or metal-to-non-metal surfaces.

Table 4. Physical properties of some metals (M) produced by aluminum/metal oxide (MO) energetic composite materials.

\begin{tabular}{cccccc}
\hline Metals & $\begin{array}{c}\text { Density } \\
\left(\mathbf{g} / \mathbf{c m}^{\mathbf{3}} \mathbf{)}\right.\end{array}$ & $\begin{array}{c}\text { Melting Point } \\
\left(\mathbf{T}_{\mathbf{m}},{ }^{\circ} \mathbf{C}\right)\end{array}$ & $\begin{array}{c}\text { Boiling Point } \\
\left(\mathbf{T}_{\mathbf{b}},{ }^{\circ} \mathbf{C}\right)\end{array}$ & $\begin{array}{c}\text { Electrical } \\
\text { Conductivity } \\
\mathbf{( S / m )}\end{array}$ & $\begin{array}{c}\text { Thermal } \\
\text { Conductivity } \\
\mathbf{( W / m} / \mathbf{K})\end{array}$ \\
\hline Indium (In) & 7.31 & 156.6 & 2072 & 11.6 & 81.6 \\
Tin (Sn) & 7.29 & 231.9 & 2602 & 9.17 & 66.6 \\
Iron (Fe) & 7.84 & 1538 & 2861 & 9.93 & 80.2 \\
Molybdenum (Mo) & 10.22 & 2623 & 4639 & 18.7 & 138 \\
Tungsten (W) & 19.3 & 3422 & 5555 & 8.9 & 174 \\
\hline
\end{tabular}

\section{Conclusions}

This investigation demonstrates the successful use of indium (III) oxide ceramic $\left(\mathrm{In}_{2} \mathrm{O}_{3}\right)$ as an oxidizer in metastable intermolecular composites. This was achieved by mixing $\operatorname{In}_{2} \mathrm{O}_{3}$ material with an aluminum nanopowder under stoichiometric conditions. Theoretical (density, and heat of reaction) and experimental (sensitivity properties and combustion rate) data were determined. A heat release of $-2.26 \mathrm{~kJ} / \mathrm{g}\left(-11.75 \mathrm{~kJ} / \mathrm{cm}^{3}\right)$ was calculated. With the use of $\operatorname{In}_{2} \mathrm{O}_{3}$ micron powder, the $\mathrm{Al} / \mathrm{In}_{2} \mathrm{O}_{3}$ energetic composite material does not show a promising reactive behavior owing to uncomplete reaction was observed in open burn experiments. In contrast, an impressive combustion reaction, with a reaction front propagation of $500 \mathrm{~m} / \mathrm{s}$ (determined in confined mode), was observed for the $\mathrm{Al} / \mathrm{In}_{2} \mathrm{O}_{3}$ composite nanomaterial. Regarding sensitivities properties, impact $(>100 \mathrm{~J})$, friction $(324 \mathrm{~N})$, and spark $(0.31 \mathrm{~mJ})$ tests revealed an $\mathrm{Al} / \mathrm{In}_{2} \mathrm{O}_{3}$ nanothermite that is insensitive to mechanical stimuli and extremely sensitive to the electrostatic discharge test. A future work would be the preparation of a spark-desensitized $\mathrm{Al} / \mathrm{In}_{2} \mathrm{O}_{3}$ reactive composition. For that, the use of a micrometer-sized indium (III) oxide fabric elaborated from an assembly of nanoparticles could be interesting. Indeed, $\mathrm{Al} / \mathrm{In}_{2} \mathrm{O}_{3}$ thermite prepared from micrometer oxidizer showed a much lower spark sensitivity $(27.71 \mathrm{~mJ} v \mathrm{vs} .0 .31 \mathrm{~mJ})$ than its $\mathrm{Al} / \mathrm{In}_{2} \mathrm{O}_{3} \_\mathrm{nm}$ counterpart. Thus, the nanostructured oxidizer fabric, mixed with nanoscale 
aluminum, would allow the formulation of a thermite combining the best properties of sensitivity and reactive behavior, associated with the micrometer and nanometer size of $\mathrm{In}_{2} \mathrm{O}_{3}$, respectively.

Supplementary Materials: The following are available online at https:/ /www.mdpi.com/article/10 $.3390 /$ jcs5070166/s1, Figure S1: Microstructure of the individual powders (A) aluminum (Al) and indium (III) oxide (B) micro, and (C) nanopowders, respectively. Figure S2: Filling up height as function of mass added for the thermite $\mathrm{Al} / \mathrm{In}_{2} \mathrm{O}_{3} \_\mathrm{nm}$ energetic composite ( $\phi=1$, series of 4 tubes). For the sake of clarity, lines are plotted. Figure S3: Filling up height as function of mass added for the thermite $\mathrm{Al} / \mathrm{In}_{2} \mathrm{O}_{3}$ nmm energetic composite ( $\phi=1$, series of 4 tubes). For the sake of clarity, lines are plotted.

Author Contributions: E.P. and P.G. carried out the experimental work and the corresponding data interpretation. P.G. suggested and guided this research, and wrote the paper. All authors have read and agreed to the published version of the manuscript.

Funding: The authors gratefully acknowledge the French National Centre for Scientific Research (CNRS), French German Research Institute of Saint-Louis (ISL, Saint-Louis, France) and University of Strasbourg (UNISTRA, Strasbourg, France) for funding.

Acknowledgments: The authors acknowledge D. Spitzer (director of NS3E, Saint-Louis, France) for his help in obtaining the ISL funding of the second-year Master's Degree internship of E. Puel. The authors express their acknowledgements to F. Oudot, Y. Boehrer (ISL, Saint-Louis, France) for the sensitivity tests and video recordings, respectively and F. Schnell (NS3E, Saint-Louis, France) for the scanning electron microscopy analysis.

Conflicts of Interest: The authors declare no conflict of interest.

\section{References}

1. Fischer, S.; Grubelich, M. Theoretical Energy Release of Thermites, Intermetallics, and Combustible Metals. In Proceedings of the 24th International Pyrotechnics Seminar, Monterey, CA, USA, 27-31 July 1998; pp. 231-286.

2. Levitas, V.I.; Pantoya, M.L.; Dikici, B. Melt-dispersion mechanism for fast reaction of aluminium particles: Extension for micron scale particles and fluorination. Appl. Phys. Lett. 2008, 92, 011921. [CrossRef]

3. Walter, K.C.; Pesiri, D.R.; Wilson, D.E. Manufacturing and Performance of Nanometric Al/MoO3 Energetic Materials. J. Propuls. Power 2007, 23, 645-650. [CrossRef]

4. Son, S.F.; Asay, B.W.; Foley, T.J.; Yetter, R.A.; Wu, M.H.; Risha, G.A. Combustion of nanoscale Al/MoO3 thermite in microchannels. J. Propuls. Power 2007, 23, 715-721. [CrossRef]

5. Dikici, B.; Pantoya, M.L.; Levitas, V. The effect of pre-heating on flame propagation in nanocomposite thermites. Combust. Flame 2010, 157, 1581-1585. [CrossRef]

6. Clark, B.R.; Pantoya, M.L.; Hunt, E.M.; Kelly, T.J.; Allen, B.F.; Heaps, R.J.; Daniels, M.A. Synthesis and characterization of flexible, free-standing, energetic thin films. Surf. Coatings Technol. 2015, 284, 422-426. [CrossRef]

7. Zakiyyan, N.A.; Wang, R.; Thiruvengadathan, C.; Staley, J.M.; Gangopadhyay, K.; Maschmann, M.R.; Gangopadhyay, S. Combustion of aluminum nanoparticles and exfoliated 2D molybdenum trioxide composites. Combust. Flame 2018, 187, 1-10. [CrossRef]

8. Sanders, V.E.; Asay, B.W.; Foley, T.J.; Tappan, B.C.; Pacheco, A.N.; Son, S.F. Reaction propagation of four nanoscale energetic composites $\left(\mathrm{Al} / \mathrm{MoO}_{3}, \mathrm{Al} / \mathrm{WO}_{3}, \mathrm{Al} / \mathrm{CuO}\right.$ and $\left.\mathrm{Bi}_{2} \mathrm{O}_{3}\right)$. J. Propuls. Power 2007, 23, 707-714. [CrossRef]

9. Sullivan, K.T.; Chiou, W.A.; Fiore, R.; Zachariah, M.R. In Situ microscopy of rapidly heated nano-Al and nano-Al/WO3 thermites. Appl. Phys. Lett. 2010, 97, 133104. [CrossRef]

10. Gibot, P.; Bach, A.; Vidal, L.; Schnell, F.; Gadiou, R.; Spitzer, D. Safer and performing energetic materials based on polyani-linedoped nanocomposites. J. Energetic Mater. 2017, 35, 136-147. [CrossRef]

11. Comet, M.; Martin, C.; Schnell, F.; Spitzer, D. Nanothermite foams: From nanopowder to object. Chem. Eng. J. 2017, 316, 807-812. [CrossRef]

12. Prakash, A.; McCormick, A.V.; Zachariah, M.R. Aero-sol-gel synthesis of nanoporous iron-oxide particles: A potential oxidiz-er for nanoenergetic materials. Chem. Mater. 2004, 16, 1466-1471. [CrossRef]

13. Plantier, K.B.; Pantoya, M.L.; Gash, A.E. Combustion wave speeds of nanocomposite $\mathrm{Al} / \mathrm{Fe}_{2} \mathrm{O}_{3}$ : The effects of Fe $\mathrm{O}_{3}$ particle synthesis technique. Combust. Flame 2005, 140, 299-309. [CrossRef]

14. Bezmelnitsyn, A.R.; Thiruvengadathan, S.; Barizuddin, D.; Tappmeyer, S.; Apperson, K.; Gangopadhyay, S. Modified nanoenergetic composites with tunable combustion characteristics for propellant applications. Propellants Explos. Pyro-Tech. 2010, 35, 384-394. [CrossRef] 
15. Zhang, W.; Yin, B.; Shen, R.; Ye, J.; Thomas, J.A.; Chao, Y. Significantly Enhanced Energy Output from 3D Ordered Macroporous Structured $\mathrm{Fe}_{2} \mathrm{O}_{3} / \mathrm{Al}$ Nanothermite Film. ACS Appl. Mater. Interfaces 2012, 5, 239-242. [CrossRef] [PubMed]

16. Hu, X.; Liao, X.; Xiao, L.; Jian, X.; Zhou, W. High-Energy Pollen-Like Porous $\mathrm{Fe}_{2} \mathrm{O}_{3} / \mathrm{Al}$ Thermite: Synthesis and Properties. Propellants Explos. Pyrotech. 2015, 40, 867-872. [CrossRef]

17. Petrantoni, M.; Rossi, C.; Conédéra, V.; Bourrier, D.; Pierre, A.; Tenailleau, C. Synthesis process of nanowired $\mathrm{Al} / \mathrm{CuO}$ thermite. J. Phys. Chem. Solids. 2010, 71, 80-83. [CrossRef]

18. Zhou, X.; Shen, R.; Ye, Y.; Zhu, P.; Hu, Y.; Wu, L. Influence of $\mathrm{Al} / \mathrm{CuO}$ reactive multilayer films additives on exploding foil initiator. J. Appl. Phys. 2011, 110, 094505. [CrossRef]

19. Yan, S.; Jian, G.; Zachariah, M.R. Electrospun Nanofiber-Based Thermite Textiles and their Reactive Properties. ACS Appl. Mater. Interfaces 2012, 4, 6432-6435. [CrossRef]

20. Sullivan, K.T.; Kuntz, J.D.; Gash, A.E. Electrophoretic deposition and mechanistic studies of nano-Al/CuO thermites. J. Appl. Phys. 2012, 112, 024316. [CrossRef]

21. Sullivan, K.T.; Kuntz, J.D.; Gash, A.E. The role of fuel particle size on flame propagation velocity in thermites with a nanoscale oxidizer. Propellants Explos. Pyrotech. 2014, 39, 407-415. [CrossRef]

22. McCollum, J.; Pantoya, M.L.; Iacono, S.T. Activating aluminum reactivity with fluoropolymer coatings for improved energetic composite combustion. ACS Appl. Mater. Interfaces 2015, 7, 18742-18749. [CrossRef] [PubMed]

23. Piekiel, N.W.; Zhou, L.; Sullivan, K.T.; Chowdhury, S.; Egan, G.C.; Zachariah, M.R. Initiation and Reaction in $\mathrm{Al} / \mathrm{Bi}_{2} \mathrm{O}_{3}$ nanothermites: Evidence for the predominance of condensed phase chemistry. Combust. Sci. Technol. 2014, 186, 1209-1224. [CrossRef]

24. Nellums, R.R.; Terry, C.B.; Tappan, C.B.; Son, S.F.; Groven, L.J. Effect of solids loading on resonant mixed $\mathrm{Al}_{-}-\mathrm{Bi}_{2} \mathrm{O}_{3}$ nanothermite powders. Propellants Explos. Pyrotech. 2013, 38, 605-610. [CrossRef]

25. Wang, L.; Luss, D.; Martirosyan, K.S. The behavior of nanothermite reaction based on $\mathrm{Bi}_{2} \mathrm{O}_{3} /$ Al. J. Appl. Phys. 2011, 110 , 74311. [CrossRef]

26. Sullivan, K.; Zachariah, M.R. Simultaneous pressure and optical measurements of nano aluminium thermites: Investigating the reaction mechanism. J. Propuls. Power 2010, 26, 467-472. [CrossRef]

27. Gibot, P.; Goetz, V. Aluminium/tin (IV) oxide thermite composite: Sensitivities and reaction propagation. J. Energetic Mater. 2020, 38, 295-308. [CrossRef]

28. Downs, A.J. Chemistry of Aluminium, Gallium, Indium, and Thallium, 1st ed.; Chapman and Hall: London, UK, 1993.

29. Shimada, S.; Sato, O.; Tsunashima, A.; Kodaira, K. Crystallization of $\operatorname{In}_{2} \mathrm{O}_{3}$ by vapour reaction. J. Cryst. Growth 1987, 80, 366-370. [CrossRef]

30. Neri, G.; Bonavita, A.; Micali, G.; Rizzo, G.; Callone, E.; Carturan, G. Resistive CO gas sensors based on $\mathrm{In}_{2} \mathrm{O}_{3}$ and $\mathrm{InSnOx}$ nanopowders synthesized via starch-aided sol-gel process for automotive applications. Sens. Actuators B Chem. 2008, 132, 224-233. [CrossRef]

31. Zhan, Z.; Jiang, D.; Xu, J. Investigation of a new $\mathrm{In}_{2} \mathrm{O}_{3}$-based selective $\mathrm{H} 2$ gas sensor with low power consumption. Mater. Chem. Phys. 2005, 90, 250-254. [CrossRef]

32. $\mathrm{Xu}$, J.; Wang, X.; Shen, J. Hydrothermal synthesis of $\mathrm{In}_{2} \mathrm{O}_{3}$ for detecting H2S in air. Sens. Actuators B Chem. 2006, 115, 642-646. [CrossRef]

33. Xu, P.; Cheng, Z.; Pan, Q.; Xu, J.; Xiang, Q.; Yu, W.; Chu, Y. High aspect ratio $\operatorname{In}_{2} \mathrm{O}_{3}$ nanowires: Synthesis, mechanism and $\mathrm{NO}_{2}$ gas-sensing properties. Sens. Actuators B Chem. 2008, 130, 802-808. [CrossRef]

34. Song, P.; Wang, Q.; Yang, Z. Biomorphic synthesis and gas response of $\operatorname{In}_{2} \mathrm{O}_{3}$ microtubules using cotton fibres as templates. Sens. Actuators B 2012, 168, 421-428. [CrossRef]

35. Wagner, T.; Sauerwald, T.; Kohl, C.-D.; Waitz, T.; Weidmann, C.; Tiemann, M. Gas sensor based on ordered mesoporous $\mathrm{In}_{2} \mathrm{O}_{3}$. Thin Solid Films 2009, 517, 6170-6175. [CrossRef]

36. Talawar, M.; Agrawal, A.; Anniyappan, M.; Wani, D.; Bansode, M.; Gore, G. Primary explosives: Electrostatic discharge initiation, additive effect and its relation to thermal and explosive characteristics. J. Hazard. Mater. 2006, 137, 1074-1078. [CrossRef]

37. Greason, W.D. Electrostatic discharge characteristics for the human body and circuit packs. J. Electrost. 2003, 59, 285-300. [CrossRef]

38. Puszynski, J.A.; Bulian, C.J.; Swiatkiewicz, J.J. Processing and ignition characteristics of aluminum-bismuth trioxide nano-thermite system. J. Propuls. Power 2007, 23, 698-706. [CrossRef]

39. Steelman, R.; Clark, B.; Pantoya, M.L.; Heaps, R.J.; Daniels, M.A. Desensitizing nano powders to electrostatic discharge ignition. J. Electrost. 2015, 76, 102-107. [CrossRef]

40. Poper, K.H.; Collins, E.S.; Pantoya, M.L.; Daniels, M.A. Controlling the electrostatic discharge ignition sensitivity of composite energetic materials using carbon nanotube additives. J. Electrost. 2014, 72, 428-432. [CrossRef]

41. Foley, T.; Pacheco, A.; Malchi, J.; Yetter, R.; Higa, K. Development of Nanothermite Composites with Variable Electrostatic Discharge Ignition Thresholds. Propellants Explos. Pyrotech. 2007, 32, 431-434. [CrossRef]

42. Bach, A.; Gibot, P.; Vidal, L.; Gadiou, R.; Spitzer, D. Modulation of the Reactivity of a WO3/Al Energetic Material with Graphitized Carbon Black as Additive. J. Energetic Mater. 2015, 33, 260-276. [CrossRef]

43. Kelly, D.G.; Beland, P.; Brousseau, P.; Petre, C.F. Electrostatic discharge sensitivity and resistivity measurements of Al nanothermites and their fuel and oxidant precursors. Cent. Eur. J. Energetic Mater. 2017, 14, 105-119. [CrossRef] 
44. Siegert, B.; Comet, M.; Muller, O.; Pourroy, G.; Spitzer, D. Reduced-Sensitivity Nanothermites Containing Manganese Oxide Filled Carbon Nanofibers. J. Phys. Chem. C 2010, 114, 19562-19568. [CrossRef]

45. Collins, E.S.; Skelton, B.R.; Pantoya, M.L.; Irin, F.; Green, M.J. Ignition sensitivity and electrical conductivity of an aluminum fluoropolymer reactive material with carbon nanofillers. Combust. Flame 2015, 162, 1417-1421. [CrossRef]

46. Kappagantula, K.; Pantoya, M.L.; Hunt, E.M. Impact ignition of aluminum-teflon based energetic materials impregnated with nano-structured carbon additives. J. Appl. Phys. 2012, 112, 024902. [CrossRef]

47. Kappagantula, K.; Pantoya, M.L. Experimentally measured thermal transport properties of aluminum? Polytetrafluoroethylene nanocomposites with graphene and carbon nanotube additives. Int. J. Heat Mass Transf. 2012, 55, 817-824. [CrossRef]

48. Pichot, V.; Comet, M.; Miesch, J.; Spitzer, D. Nanodiamond for tuning the properties of energetic composites. J. Hazard. Mater. 2015, 300, 194-201. [CrossRef] [PubMed]

49. Gibot, P.; Goetz, V. $\mathrm{SnO}_{2}$-Polyaniline composites for the desensitization of $\mathrm{Al} / \mathrm{SnO}_{2}$ thermite composites. J. Appl. Polym. Sci. 2020, 137, 48947. [CrossRef]

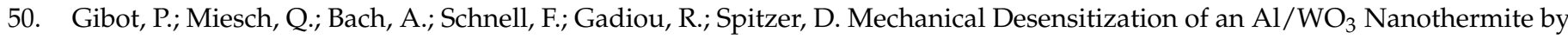
Means of Carbonaceous Coatings Derived from Carbohydrates. J. Carbon Res. 2019, 5, 37. [CrossRef]

51. Ohkura, Y.; Rao, P.M.; Zheng, X. Flash ignition of Al nanoparticles: Mechanism and applications. Combust. Flame 2011, 158, 2544-2548. [CrossRef]

52. Haussonne, J.M. Céramiques Pour L'électronique et L'électrotechnique; EPFL Press: Lauzane, Switzerland, 2002. (In French)

53. The North Atlantic Treaty Organization. NATO Standardization Agreement (STANAG) on Explosives, Impact Sensitivity Tests, No. 4489, 1st ed.; NATO: Brussels, Belgium, 17 September 1999.

54. The North Atlantic Treaty Organization. NATO Standardization Agreement (STANAG) on Explosive, Friction Sensitivity Tests, No. 4487, 1st ed.; NATO: Brussels, Belgium, 22 August 2002.

55. Gibot, P. Templated synthesis of $\mathrm{Cr}_{2} \mathrm{O}_{3}$ material for energetic composites with high performance. Solid State Sci. $2019,94,162-167$. [CrossRef]

56. Weast, R.C.; Lide, D.R. Handbook of Chemistry and Physics, 68th ed.; Edition CRC Press: Boca Raton, FL, USA, 1986; pp. 1987-1988. 